\title{
Fravel, Taylor. 2019. Active Defense: China's Military Strategy since 1949. Princeton University Press, 396 pp. $\$ 24.95$ (Paperback)
}

Irrespective of the historical period, there are always events of central importance which shape trends in international relations. Around them formed systems, paradigms, contours of rivalry, often turning into wars. Sometimes, periods of peaceful coexistence occur. According to numerous political scientists, such an event is the growing rivalry between the United States and China. Particular prerequisites for the growing tension were noticeable even during the presidency of Barack Obama. During Donald Trump's mandate in the White House, the totality of contradictions reached a red line, which resulted in further tightening of their relations. Under the current US President, Joseph Biden, US - Chinese relations have reached, perhaps, a certain point, after which we can almost talk about an open confrontation on multiple fields, such as the trade, economy, technology, cyberspace, human rights, the military and geopolitics.

Understanding China's military strategy has never been more important than it is today. With four decades of rapid economic growth, China is now the world's second-largest economy. Apart from the United States, China now spends more on defence than any other country. With two million soldiers in uniform, its Army is one of the largest in the world. Yet some of the most important questions about China, including how it will use its growing military capabilities and spending, go largely unanswered. A key part of the answer lies in comprehending its military strategy. Understanding China's past and present approaches to strategy provides a crucial baseline for assessing future changes (p. 3).

The author of this monograph, Taylor Fravel, is the Director of the Security Studies Program at MIT and a world-renowned expert on China's armed forces. The monograph under review Active Defense: China's Military Strategy since 1949 consists of eight chapters, each exploring certain problems and stages of reforms of the Chinese army and military ideology. The book rests on a wide range of sources, from academic research to Chinese data, all of which create a depth of the issues elaborated in the book.

The goals and objectives of this book are to explain when, why, and how China has pursued major change in its military strategy. The research methodology is a twofold argument: China has pursued major changes in military strategy in response to shifts in the conduct of warfare - but only when the CCP (Chinese Communist Party) is united and stable. In addition, the views on military affairs and the army reflect the ideological dog- 
mas of the Chinese state. Hence, according to the author, the use of strategic lexica, such as "active defense" and "people's war" (pp. 4-5).

The book is a deeply structured theoretical and narrative study on the genesis, evolution and history of the formation of military thought in China and the reforms of the PLA (People's Liberation Army). Fravel's significant contribution to political science is a schematic illustration of his theoretical hypotheses, which deserves some attention (p. 25). The most interesting is the current stage of Chinese army transformation. Thus, the author writes that "the third major change in China's military strategy is the adoption of the 1993 strategic guidance, which required that the PLA could wage and win a local war on its periphery, which would be characterized by high technology" (p. 25). In the early 1990s, senior CCP and military leaders claimed that the regional security situation was "the best" since 1949, mainly due to the dispersal of the Soviet threat. Nevertheless, despite the absence of a clear and real threat to national security, China has adopted its most ambitious military strategy to date, seeking capacity development to conduct joint operations in a wide range of unforeseen circumstances on its periphery (pp. 6-7).

Significant strategy changes of military affairs took place between 2004 and 2014, and they were associated with the beginning of the information society. The focus of Chinese strategists has changed towards "winning local wars under informatised conditions" (p. 182). In chapter seven, the author explores the changes in the ideology of the military strategy, when the paradigm has focused even more on the latest technologies: the strategic guideline was adjusted again to further emphasise normalisation in "winning informatised local wars" (p. 182).

Chapter eight analyses the evolution of China's nuclear strategy. China's nuclear strategy is perplexing for two reasons. One reason is that, based on achieving deterrence through guaranteed retaliation, it has not changed significantly since China detonated its first nuclear device in October 1964. Moreover, China has not sought to change its strategy to overcome its vulnerability to a first attack by the United States or the Soviet Union. The chapter contains an essential and bold hypothesis which states that the reform and strategic management of China's nuclear potential are not handled by the army but by the CCP leadership. "Nuclear strategy was considered a matter of national policy, determined by the party leadership in consultation with senior military officers, as well as civilian scientific experts. Although senior military officers, especially in the 1950s, advocated developing a major nuclear program, these proposals were consistently rejected. Since the nuclear strategy was never delegated to the PLA, the views on nuclear weapons held by China's top party leaders, especially Mao Zedong and Deng Xiaoping, have had a powerful impact even today" (p. 237). This specificity, according to the author, is connected to the peculiarity of the political regime and the strategic vision of the role of nuclear weapons in Chinese national defence. Because these leaders viewed the value of nuclear weapons as limited to deterring nuclear coercion or attacks, the nuclear strategy has not been integrated with conventional military strategy (pp. 236-269). 
Fravel's analyses the reflections of the Chinese top political and military leadership on the conflict events in world politics and comes to some interesting conclusions. Even though China did not participate in many wars after the end of World War II, their presence prompted China to make changes in its war strategy, which the author describes in the following manner: "The lessons from contemporary conflicts should be especially relevant for developing countries or late military modernizers, such as China, that may not yet be peer competitors but that seek to strengthen their armed forces" (p. 15). Moreover, Fravel argues that recent conflicts should force China most likely to change its military strategy in response to these conflicts (p. 33).

Since 1949, ten interstate wars have involved a great power or its client using the great power's equipment and doctrine. These wars are the 1950-53 Korean War, the 1967 Arab - Israeli War, the 1971 Indo - Pakistani War, the 1973 Arab - Israeli War, the 1980-88 Iran - Iraq War, the 1982 Lebanon War, the 1982 Falklands War, the 1990-91 Gulf War, the 1999 Kosovo War, and the 2003 Iraq War (p. 83). However, the author forgets to mention the short Sino - Vietnamese War in 1979, which had somewhat ambiguous consequences for Beijing and showed the imperfection of its armed forces. Although China today claims that this war was won, there are different opinions in the academic community on this subject. It seems that the author should have paid more attention to this conflict and its impact on the reforms of the Chinese army.

The monograph also contains other theoretical conclusions. Analysing the motivation for military reforms per se, the author refers to Kenneth Waltz. The latter argues that because international politics is "a competitive realm" states will copy and emulate the most successful military practices in the system. While criticising individual theoretical hypotheses, the author agrees with Waltz's statement, in which he suggests, "contending states imitate the military innovations contrived by the country of the greatest capability and ingenuity," including its weapons and strategies. Waltz also suggests that emulation will most likely occur among peer competitors or "contending states". According to this theory, the author concludes that China will coordinate its reforms with similar processes in advanced countries, including the United States. In fact, we can say that Beijing, one way or another, will copy the best practices in militarily developed countries.

Let us consider one of Fravel's more important hypotheses in more depth. He argues that significant reforms in socialist states, such as China, with party armies and the structure of relations between civil and military, allow senior officers to initiate changes in strategy under certain conditions. An example of such a situation is when the party is united and delegates the responsibility for military affairs to the armed forces. (p. 16). The author argues that the vanguard of army reforms is the party leadership, not the military. Fravel confirms his hypothesis with numerous Chinese sources and earlier theoretical developments. Thus, referring to the classic work of Samuel Huntington - The Soldier and the State - Fravel stipulates that "in socialist states, the more appropriate subject of study is not civil-military relations, but 'party-military' relations" (p. 46). 
Delegating military responsibilities to the party elite is not associated with the possible coups fear. With party armies in most socialist states, this problem does not exist. There have been few military-led coups in communist countries, especially those in which the regimes were established through violent revolutions (p. 47). So, by analogy with the USSR, Amos Perlmutter and William LeoGrande ${ }^{1}$ thought to develop a unified theory of civil-military relations in socialist states. They explain that socialist states are characterised by the political hegemony of a "vanguard" party. This hegemony requires the subordination of all non-party institutions, including the military, to the party and not to the state (which the party controls). According to the author, modern China largely retains the system of management and army practice, which took place in the USSR.

South and East Asia is a region of increased geopolitical activity and a colossal number of major actors in international relations. The rapid and systematic growth of China, India, Japan, South Korea and other players makes this region a modern Ecumene. Fravel's book makes a profound contribution to science by exploring the essential aspects of Chinese military power in the context of regional and international security. From the point of view of regional studies, this monograph is also a highly relevant, must-read piece on South-East Asia.

This book deserves close attention from the academic community and all those interested in military theory and China. Despite minor flaws, the monograph contributes to the understanding of the transformation in the Chinese army, its strategic views, approaches and concepts used by the political and military leadership.

Georgi Asatryan is a Research Fellow of the Plekhanov Russian University of Economics and at The Institute of Scientific Information on Social Sciences of the Russian Academy of Sciences. E-mail: asatryan.ge@rea.ru.

1 Perlmutter, Amos, and William M. LeoGrande. 1982. "The Party in Uniform: Toward a Theory of Civil-Military Relations in Communist Political Systems." The American Political Science Review 76 (4): 778-789. doi:10.2307/1962970. 